\title{
Factors affecting the mortality at patients with burns: Single centre results
}

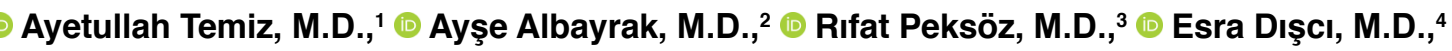 \\ (D) Ercan Korkut, M.D., ${ }^{4}$ ㄴ Yusuf Tanrıkulu, M.D., ${ }^{5}$ ㄴ Yavuz Albayrak, M.D. ${ }^{4}$
}

\author{
${ }^{1}$ Department of General Surgery, Erzurum Regional Training and Research Hospital, Erzurum-Turkey \\ ${ }^{2}$ Department of Infectious Diseases, Atatürk University Faculty of Medicine, Erzurum-Turkey \\ ${ }^{3}$ Department of General Surgery, Malazgirt State Hospital, Muş-Turkey \\ ${ }^{4}$ Department of General Surgery, Atatürk University Faculty of Medicine, Erzurum-Turkey \\ ${ }^{5}$ Department of General Surgery, KTO Karatay University Faculty of Medicine, Konya-Turkey
}

\begin{abstract}
BACKGROUND: Burns are a primary cause of mortality along with the severe physical and psychological morbidities in patients and their families. Such kinds of injuries bring about considerable financial burdens due to the treatment processes and sequels. The present study aims to investigate the factors that affect the mortality of burns.
\end{abstract}

METHODS: The archives files of the patients admitted because of burn injuries in our burn centre between September 2008 and December 2016 were examined in this study. Some of the lab values, such as age, sex, percentage of total burn surface area (TBSA), referral status, burning site, degree of burns, time of admission to hospital, aetiology of burning, blood and blood products collection, complete blood count, routine biochemistry, coagulation parameters, C-reactive protein (CRP), sedimentation rate, neutrophil-to-lymphocyte ratio (NLR) and platelet-to-lymphocyte ratio (PLR), were examined while evaluating the patients' mortalities.

RESULTS: A total of I 33 patients were included in this study. The patient's age $(p=0.00 \mathrm{I})$, the degree of burns $(p<0.00 \mathrm{I})$, surface area of burns $(p<0.00 \mathrm{I})$, the time of hospital admission $(p<0.00 \mathrm{I})$, burning aetiology $(p=0.006)$, erythrocyte suspension, fresh frozen plasma, along with the administration of albumin transfusion $(p<0.00 \mathrm{I})$, mean platelet volume $(M P V)(p=0.028), N L R(p<0.00 \mathrm{I})$ and PLR $(p<0.030)$ values were found to be associated with mortality in patients with burns.

CONCLUSION: In this study, age, burn grade, TBSA, hospital admission time, burn aetiology, erythrocyte, fresh frozen plasma and albumin transfusion, MPV, NLR and PLR values were found to be associated with mortality in patients with burns. With this study, it is possible to produce the treatment guidelines to reduce mortality by taking these parameters into consideration, which were determined to be associated with mortality while evaluating the patients with burns.

Keywords: Burn; mean platelet volume; neutrophil-to-lymphocyte ratio; platelet-to-lymphocyte ratio.

\section{INTRODUCTION}

Burns are the fourth most common type of trauma worldwide, followed by traffic accidents, falls and interpersonal violence and are a major public health problem among all injuries. ${ }^{[1-3]}$ Burns are a major cause of mortality along with severe physical and psychological morbidities in patients and their families. In addition, such kinds of injuries impose con- siderable financial burdens due to treatment processes and sequels. ${ }^{[4,5]}$ Every year, approximately 200,000 people around the world die of burn injuries. ${ }^{[3]}$ Various fires, scalding agents, chemicals, electricity and radiation are seen as the causes of burning and all these agents cause burns of varying severity, thereby resulting in severe morbidity and mortality. ${ }^{[6]}$ In general, the mortality risk factors for patients with burns are gender, age, total burn surface area (TBSA), presence of in-

Cite this article as: Temiz A, Albayrak A, Peksöz R, Dışcı E, Korkut E, Tanrıkulu Y, et al. Factors affecting the mortality at patients with burns: Single centre results. Ulus Travma Acil Cerrahi Derg 2020;26:777-783.

Address for correspondence: Yavuz Albayrak, M.D.

Atatürk Üniversitesi Tıp Fakültesi, Genel Cerrahi Anabilim Dalı, Erzurum, Turkey

Tel: +90 442 - 2422275 E-mail: yavuzalbayrakdr@gmail.com

Ulus Travma Acil Cerrahi Derg 2020;26(5):777-783 DOI: 10.14744/tjtes.2020.37862 Submitted: 18.1 I.2019 Accepted: 02.02.2020 Online: 10.09.2020

Copyright 2020 Turkish Association of Trauma and Emergency Surgery 
halation damage, co-morbid disease and other concomitant trauma. ${ }^{[7,8]}$ With advances in intensive care and burn care, the survival outcomes of patients with severe burn injuries over the past ten years have improved significantly. ${ }^{[9]}$

\section{MATERIALS AND METHODS}

This study received approval from the Ataturk University Faculty of Medicine clinical research Ethics committee (dated 13/03/2019 and numbered 02-0I). Of the 30I patients with BSA of $15 \%$ and over who were referred to Erzurum Regional Training and Research Hospital Burn Center between September 2008 and December 2016 from other centres, 133 patients (whose full information could be obtained) were included in this study.

The files of these patients were retrieved from the electronic archives and their data were retrospectively examined. The patients were divided into two groups as follows: survivors and the deceased patients. Some of the lab values, such as age, sex, percentage of TBSA, referral status, burning site, degree of burn, time to admission to hospital, aetiology of burning, blood and blood products collection, complete blood count, routine biochemistry, coagulation parameters, C-reactive protein (CRP), sedimentation rate, neutrophil-to-lymphocyte ratio (NLR) and platelet-to-lymphocyte ratio (PLR), were examined while evaluating the patients' mortalities.

\section{Statistical Analysis}

Statistical analyses were performed by employing SPSS 15.0 software (SPSS Inc., Chicago, IL, USA). The distribution of data was determined using the Kolmogorov-Smirnov test. Continuous variables were expressed as mean \pm std. deviation, whereas categorical variables as frequency and percentage. Continuous variables were compared with the independent sample t-test or Mann-Whitney $U$ test and categorical variables were compared using Pearson's Chi-square test for two groups. A p-value of less than 0.05 was considered statistically significant.

\section{RESULTS}

Of the admitted patients, 69 (52.7\%) were males, and 64 (47.3\%) were females. Of the deceased patients, eight $(6.1 \%)$ patients were males and 16 (12.2\%) patients were females. There was no statistically significant difference between the two groups $(p=0.070)$. The mean ages of surviving patients and deceased patients were $15.17 \pm 18.23$ and $33.04 \pm 26.64$, respectively. There was a statistically significant difference between the two groups $(p=0.001)$. According to the degree of burns, two of the surviving patients had first-degree burns, 66 patients had superficial second-degree burns, 12 patients had deep second-degree burns, 29 patients had third degree burns, whereas in the deceased patients, one patient had superficial second-degree burnseight patients had deep second-degree burns and 15 patients had third-degree burns.
There was a statistically significant difference between the two groups $(p<0.00 \mathrm{I})$.

The percentages of TBSA in surviving patients and deceased patients were 22.92 \pm 9.11 and 52.04 23.52 , respectively. There was a statistically significant difference between the two groups $(p=0.001)$. A total of five of the 96 patients with a TBSA ratio of $16 \%-30 \%$ were deceased patients, whereas 19 of the 37 patients with a TBSA ratio higher than $30 \%$ were deceased patients. Again, there was a statistically significant difference between the two groups $(<0.00 \mathrm{I})$.

Of the II 4 patients admitted directly, six were deceased patients, whereas 18 of the 19 patients referred from another centre were deceased patients. There was a significant difference between the two groups $(<0.00 \mathrm{I})$.

According to the burn site, among the surviving patients, 91 patients were burned at home, two patients at work and 16 patients in an open area, whereas among the deceased patients, 19 patients were burned at home, one patient at work and four patients in an open area. There was no statistically significant difference between the two groups $(p=0.752)$.

Patients were divided into two groups as early and late arrivals according to the admission hours. Accordingly, patients who were admitted in the first four hours of the event were defined as early applicants; whereas, patients who were admitted four hours after the event were defined as late applicants. In total, four of 80 patients who applied early were deceased patients, whereas 20 of the 53 patients who were admitted late were deceased patients. There was a statistically significant difference between the two groups $(p<0.001)$. The demographic characteristics of the patients are presented in Table I.

According to the aetiology of burning, the largest group of patients discharged with healing were 57 patients with hot water burns, 22 patients with flame burns, 12 patients with tandoori burns, nine patients with home electrical burns, four patients with milk burns, three patients with hot water burns, one patient with a lightning strike and one patient with sand contact burns. Concerning deceased patients, eight patients had hot water burns, 14 patients had flame burns and two patients had tandoori burns. There was a statistically significant difference between the two groups concerning aetiology of burn $(p=0.006)$ (Table 2).

Of the 76 patients receiving erythrocyte suspension, five patients were deceased patients, whereas 19 of 57 patients without erythrocyte suspension were deceased patients. There was a statistically significant difference between these two groups $(p<0.001)$. Of the 65 patients receiving fresh frozen plasma, one patient was a deceased patient, whereas 23 out of the 68 patients were deceased patients. There was a statistically significant difference between these two groups 
Table I. Comparison of the groups according to general demographic data

\begin{tabular}{|c|c|c|c|}
\hline & $\begin{array}{c}\text { Alive } \\
(n=109)\end{array}$ & $\begin{array}{c}\text { Deceased } \\
(n=24)\end{array}$ & $\mathbf{p}$ \\
\hline Age & $15.17 \pm 18.23$ & $33.04 \pm 26.64$ & 0.001 \\
\hline Gender & & & 0.070 \\
\hline Male & 61 & 8 & \\
\hline Female & 48 & 16 & \\
\hline Burn percentage & $22.92 \pm 9.11$ & $52.04 \pm 23.52$ & $<0.001$ \\
\hline Burn percentage group & & & $<0.001$ \\
\hline$\leq 15 \%$ & 0 & 0 & \\
\hline $16-30 \%$ & 91 & 5 & \\
\hline$\geq 31 \%$ & 18 & 19 & \\
\hline Referral status & & & $<0.001$ \\
\hline Direct admission & 108 & 6 & \\
\hline Referred & 1 & 18 & \\
\hline Burn location & & & 0.752 \\
\hline Home & 91 & 19 & \\
\hline Workplace & 2 & I & \\
\hline Open area & 16 & 4 & \\
\hline Burn grade & & & $<0.001$ \\
\hline Superficial Ist degree & 2 & 0 & \\
\hline Superficial $2^{\text {nd }}$ degree & 66 & 1 & \\
\hline Deep & 12 & 8 & \\
\hline Deep+superficial & 29 & 15 & \\
\hline \multicolumn{4}{|l|}{$2^{\text {nd }}$ degree } \\
\hline $\begin{array}{l}\text { Time elapsed for } \\
\text { admission }\end{array}$ & & & $<0.001$ \\
\hline$\leq 4$ hours & 76 & 4 & \\
\hline $2-4$ hours & 33 & 20 & \\
\hline
\end{tabular}

Table 2. Comparison of the groups according to the aetiology of burning

\begin{tabular}{lccc}
\hline & $\begin{array}{c}\text { Alive } \\
(\mathbf{n = 1 0 9 )}\end{array}$ & $\begin{array}{c}\text { Deceased } \\
(\mathbf{n = 2 4 )}\end{array}$ & $\mathbf{p}$ \\
\hline Burning by hot water & 57 & 8 & 0.006 \\
Flame burn & 22 & 14 & \\
Tandoori burn & 12 & 2 & \\
House electricity burn & 9 & 0 & \\
Milk burn & 4 & 0 & \\
Tea water burn & 3 & 0 & \\
Lightning strike & 1 & 0 & \\
Sand contact burn & 1 & 0 \\
\hline
\end{tabular}

$(p<0.001)$. Of the 99 patients who underwent albumin transfusion, seven patients were deceased patients, whereas 17
Table 3. Comparison of the groups according to blood and blood products transfusion status

\begin{tabular}{lccc}
\hline & $\begin{array}{c}\text { Alive } \\
(\mathbf{n}=109)\end{array}$ & $\begin{array}{c}\text { Deceased } \\
(\mathbf{n}=\mathbf{2 4})\end{array}$ & $\mathbf{p}$ \\
\hline $\begin{array}{l}\text { Erythrocyte suspension } \\
\text { transfusion }\end{array}$ & & & \\
$\quad$ Yes & 71 & 5 & $<0.001$ \\
$\quad$ No & 38 & 19 & \\
$\begin{array}{l}\text { Fresh frozen plasma } \\
\text { transfusion }\end{array}$ & & & \\
$\quad$ Yes & & & \\
$\quad$ No & 64 & 1 & $<0.001$ \\
Albumin transfusion & 45 & 23 & \\
$\quad$ Yes & & & \\
No & 92 & 7 & $<0.001$ \\
\hline
\end{tabular}

Table 4. Comparison of the groups according to laboratory findings

\begin{tabular}{lccc}
\hline & $\begin{array}{c}\text { Alive } \\
(\mathbf{n}=109)\end{array}$ & $\begin{array}{c}\text { Deceased } \\
(\mathbf{n}=\mathbf{2 4})\end{array}$ & $\mathbf{p}$ \\
\hline Haemoglobin & $13.56 \pm 2.92$ & $14.52 \pm 3.50$ & 0.635 \\
WBC & $18.66 \pm 10.27$ & $22.50 \pm 11.20$ & 0.116 \\
Eosinophils & $0.66 \pm 0.99$ & $0.14 \pm 0.26$ & 0.025 \\
Platelet & $402.95 \pm 181.80$ & $344.20 \pm 171.65$ & 0.169 \\
MPV & $7.63 \pm 2.36$ & $8.07 \pm 1.24$ & 0.028 \\
Glucose & $147.92 \pm 70.21$ & $184.12 \pm 117.35$ & 0.234 \\
BUN & $29.60 \pm 12.71$ & $30.84 \pm 17.98$ & 0.956 \\
Creatinine & $0.59 \pm 0.77$ & $1.47 \pm 3.35$ & 0.001 \\
Sodium & $135.50 \pm 13.52$ & $138.46 \pm 6.35$ & 0.254 \\
Potassium & $4.46 \pm 0.67$ & $4.29 \pm 0.77$ & 0.041 \\
Calcium & $8.95 \pm 1.01$ & $7.42 \pm 1.20$ & $<0.001$ \\
AST & $59.30 \pm 83.86$ & $58.16 \pm 29.75$ & 0.081 \\
ALT & $33.12 \pm 41.27$ & $30.04 \pm 24.01$ & 0.146 \\
Albumin & $3.80 \pm 0.73$ & $2.56 \pm 0.70$ & $<0.001$ \\
INR & $1.09 \pm 0.19$ & $1.22 \pm 0.25$ & 0.010 \\
Sedimentation & $15.04 \pm 22.51$ & $8.62 \pm 17.60$ & 0.001 \\
CRP & $24.76 \pm 49.81$ & $39.35 \pm 56.73$ & 0.173 \\
NLR & $6.34 \pm 12.13$ & $12.96 \pm 9.70$ & $<0.001$ \\
PLR & $52.77 \pm 94.30$ & $46.56 \pm 31.34$ & 0.030 \\
\hline & & & \\
\hline & & &
\end{tabular}

WBC: White blood cell; BUN: Blood urea nitrogen; AST: Aspartate aminotransferase; ALT: Alanine aminotransferase; INR: International normalized ratio; CRP: C-reactive protein; NLR: Neutrophil-to-lymphocyte ratio; PLR: Platelet-to-lymphocyte ratio.

out of the 34 patients without transfusion were deceased patients. There was a statistically significant difference between these two groups $(p<0.001)$ (Table 3$)$. 
When patients were evaluated according to laboratory values, there was a statistically significant difference between eosinophils, MPV, creatinine, potassium (K), calcium (Ca), albumin, international normalized ratio (INR), sedimentation, NLR, PLR values between the survivors and deceased survivors or burns, whereas among the haemoglobin $(\mathrm{Hg})$, white blood cell (WBC), platelets (PLT), glucose, blood urea nitrogen (BUN), sodium ( $\mathrm{Na}$ ), aspartate aminotransferase (AST), alanine aminotransferase (ALT) and CRP values, there was no statistically significant difference between the two groups (Table 4).

\section{DISCUSSION}

Skin is one of the most important organs of the body and the largest organ that covers our body. Heat regulation, the role of sensation, protection from the external environment and having immunologic functions increase the importance of the skin even more. As a result of burning injury, in addition to the loss of functions, a life-threatening situation may also arise. ${ }^{[8]}$ Every year, millions of people in the world are affected by burns. Half of them consist of children, and one-fourth of these cases are of severe burns. Therefore, patients with burns should be treated as serious trauma patient. ${ }^{[10]}$ Advanced age, large TBSA and the presence of inhalation injury are the factors affecting the mortality rate of patients with burns. ${ }^{[1-13]}$ In addition, other factors, such as the presence of shock, the presence of sepsis and thrombocytopenia, have been reported to affect mortality rates during the admission..$^{[14-17]}$

In our study, the relationship between mortality in patients with burns and gender, age, degree of burn, burn percentage, aetiology, receiving erythrocyte suspension, receiving fresh frozen plasma, albumin, haemogram and biochemical values were evaluated.

\section{Gender and Age}

The majority of the studies have reported that the female gender is a risk factor for mortality. ${ }^{[18-20]}$ Zarei et al. ${ }^{[21]}$ reported that the mortality rate was higher in men. In a study conducted by Brusselaers, ${ }^{[22]}$ no statistically significant difference was reported between males and females concerning mortality. In our study, similar to Brusselaers' study, no statistically significant difference was found between males and females concerning gender. In the burns literature, it has been reported that age plays a key role in the relationship with mortality, especially in children and elderly people. ${ }^{[23-25]}$ Other studies examining the relationship between age and mortality have shown a marked increase in mortality in children younger than two years old as compared with those older than two years of age. ${ }^{[25]}$ Another study reported that the mortality rate was highest in children. ${ }^{[26]} \mathrm{A}$ study conducted by Tiryaki et al. ${ }^{[27]}$ on patients with electrical burns reported that elderly people were a large number of deceased ones in such cases. In our study, when we compared the survivors and deceased patients, we concluded that the deceased survivors of burns constitute the older group and this was consistent within the literature. In our study, increased mortality was found with increased age.

\section{Burn Degree}

Albayrak et al. reported that tandoori burns caused deeper burns as compared to other types of burns. Therefore, morbidity and mortality rates are reported to be higher in the cases of tandoori burns. ${ }^{[28]}$ Zarei et al. ${ }^{[1]}$ revealed that second- and third-degree burns were a risk factor in mortality rates. A study conducted by Kaya et al. ${ }^{[29]}$ regarding the electrical burns reported that there was a significant increase in mortality in the third-degree burns group as compared to the first- and second-degree burns groups. Lip et al. ${ }^{[30]}$ reported that the mortality rates in patients with full-thickness burns were higher than those in the patients with partial-thickness burns. In our study, we also concluded that the increase in mortality was parallel with the increase in the degree of burns.

\section{Burn Percentage}

Some studies have reported that BSA is an independent risk factor in determining mortality. ${ }^{[24,31-33]}$ In some studies, the BSA of the $70 \%-79 \%, 80 \%-89 \%$ and more than $90 \%$ of the burns were reported to have a mortality rate of $51.1 \%, 70.6 \%$ and $82.6 \%$, respectively. ${ }^{[31,33,34]} \mathrm{A}$ study reported that a burn area of more than $20 \%$ was an important predictor factor in determining the mortality rate. ${ }^{[30]}$ In a study, the mortality rate was found to be two-thirds higher in a burn patient group with TBSA between 21 and $30 \%$ than the burns patient group with TBSA between II and 20\%. ${ }^{[35]}$ Also, in our study, five of the 96 patients with burn percentage of 15 and $30 \%$ were deceased patients, whereas 19 of the 37 patients with burn percentage higher than $30 \%$ were deceased patients. Our results, too, were consistent with the literature.

\section{Admission Time}

A study, which included 235 paediatric patients in our paediatric patient group, reported that two people were deceased, and two of these deceased patients were brought to hospital 24 hours after the incident of burning. ${ }^{[36]}$ In this study, we found that mortality was significantly higher in the patient group who applied to our clinic after the four hours following the occurrence of the event. The late admission of patients with burns to the hospital causes a delay in both emergency fluid resuscitation and burn wound care treatment. ${ }^{[37,38]}$ In addition, patients who do not apply to health institutions after burns generally use traditional treatment methods, and burn wound infections occur as a result of these incorrect treatments. ${ }^{[39,40]}$ All of these are the causes of mortality in the patients admitted late to the hospital after the incident of burning.

\section{Burning Aetiology}

Previously conducted studies reported that the most common cause of death in patients with burns was flame burns. ${ }^{[4,21,41-43]}$ 
The pathogenesis of electrical burns has certain differences concerning the other types of burns (6). A study conducted on 964 patients in Iran by Aghazadeh et al. ${ }^{[44]}$ reported that death arose from scalding with flame, chemicals and hot liquid, respectively. Al et al. ${ }^{[26]}$ in reported that a total of 624 patients $(76.5 \%)$ were scalded, of them, 192 patients $(23.5 \%)$ had flame-induced burns, 18 patients $(9.4 \%)$ had burns due to flames, 32 patients $(5.1 \%)$ died due to scald burns and the effects of flame burns on mortality were statistically significant. In our study, the highest mortality rate arose from flame burns and, then, by the scald burns, which was consistent with the literature. It can be concluded that the most common cause of mortality in flame burns may be because flame burns lead to a larger BSA and cause deeper burns.

\section{Administration of Erythrocyte}

Koljonen et al. found that the mortality of the patients with burns undergoing transfusion was five times higher than the mortality of the patients without transfusion. ${ }^{[45]}$ Although some studies in the literature have reported a high mortality rate in patients undergoing transfusion, this relationship could not be found in most of the studies on this matter. ${ }^{[46-50]}$ In our study, we also concluded that the administration of erythrocyte suspension reduces mortality.

\section{Administration of Fresh Frozen Plasma}

Lu et al. ${ }^{[49]}$ reported that plasma transfusion is associated with mortality. Previous research works have claimed that transfusions can facilitate the formation of serious infections by suppressing the immune system, thereby increasing the mortality rate. ${ }^{[51,52]}$ Fresh frozen plasma should be used in the event of severe bleeding or coagulopathy; however, it is recommended that early and aggressive plasma transfusion should be performed if burn wound excisions are performed in patients with severe coagulopathy. ${ }^{[53-55]}$ In our study, it was found that mortality was higher in the group without FFP administration.

\section{Administration of the Albumin}

Melinyshyn et al. compared the two groups with and without routine albumin. In this study, some parameters, such as length of hospital stay, wound healing time and mortality, were compared and no difference was found between the two groups. It was also reported that the treatment costs were higher in the albumin-treated group. The results of this study concluded that the administration of albumin in patients with burns increased the cost of treatment and had no benefits. ${ }^{[56]}$ A different study reported that albumin resuscitation might reduce fluid leakage and the negative effects of excessive fluid administration. ${ }^{[57]} A$ sub-group evaluation performed in the Cochrane meta-analysis reported that the administration of albumin increased the mortality in patients with burns, whereas the results of Wilkes meta-analysis did not increase the mortality and had a neutral effect. ${ }^{\left[{ }^{[5,59]}\right.}$ Another meta-analysis study reported that albumin was not beneficial. ${ }^{[60]}$ Our study concluded that the use of albumin reduces mortality. Although our results were consistent with a small portion of the literature, it was found to be incompatible with most of the research works in literature.

\section{MPV}

MPV is used as an inflammatory marker in some diseases, such as sepsis, thrombosis, acute appendicitis and respiratory distress syndrome. ${ }^{[61,62]}$ To date, we have not found a study examining MPV mortality in patients with burns. Our study showed that MPV levels were significantly higher in deceased patients than in survivors.

\section{NLR}

NLR indicates the ratio of neutrophils and lymphocytes. NLR is shown as one of the new markers of systemic inflammation. ${ }^{[63]}$ Fuss et al. ${ }^{[64]}$ reported that NLR is significantly higher in patients with burns along with sepsis. In our study, we evaluated burn patients with sepsis, along with all the burn trauma patients. In conclusion, we found a higher rate of NLR in patients with the mortal course.

\section{PLR}

Recently, PLR has been shown to be an important new marker of systemic inflammation, such as NLR. ${ }^{[65]}$ To our knowledge, there was no study on PLR regarding the patients with burns. Our study is in contrast with many other studies on other pathologies in the literature; however, it is in parallel with the small number of studies, i.e., PLR was found to be lower in the group with deceased patients.

Our study was conducted on 133 burn patients, and the factors, such as age, degree of burn, admission time, aetiology of burning, erythrocyte, FFP and albumin transfusion, MPV, NLR and PLR values of the patients were found to be associated with mortality in patients with burns. This study was limited to one centre's experience. Even within one healthcare system, it remains difficult to match and carefully compare data, mostly because of different treatment approaches and selection of outcome parameters. Future studies can determine the factors that affect the mortality of burns and may ensure the development of treatment guidelines that will decrease the mortality of the patients with burns.

Ethics Committee Approval: Approved by the local ethics committee.

Peer-review: Internally peer-reviewed.

Authorship Contributions: Concept: A.T., Y.A.; Design: Y.A.; Supervision: Y.A.; Materials: A.T., R.P., E.D., E.K., Y.T.; Data: A.T., A.A., R.P., E.D., E.K., Y.T.; Analysis: Y.A., A.A.; Literature search: Y.A.; Writing: Y.A.; Critical revision: Y.A.

Conflict of Interest: None declared.

Financial Disclosure: The authors declared that this study has received no financial support. 


\section{REFERENCES}

1. Forjuoh SN. Burns in low- and middle-income countries: a review of available literature on descriptive epidemiology, risk factors, treatment, and prevention. Burns 2006;32:529-37. [CrossRef]

2. Peck MD, Kruger GE, van der Merwe AE, Godakumbura W, Ahuja RB. Burns and fires from non-electric domestic appliances in low and middle income countries Part I. The scope of the problem. Burns 2008;34:303-11. [CrossRef]

3. Mathers C, Fat DM, Boerma JT. The global burden of disease: 2004 update. Geneva: World Health Organization; 2008.

4. Macedo JL, Santos JB. Predictive factors of mortality in burn patients. Rev Inst Med Trop Sao Paulo 2007;49:365-70. [CrossRef]

5. Mashreky SR, Rahman A, Chowdhury SM, Giashuddin S, SvanstrOm L, Linnan M, et al. Epidemiology of childhood burn: yield of largest community based injury survey in Bangladesh. Burns 2008;34:856-62.

6. Bekerecioğlu M, Yüksel F, Peker F, Karacaoğlu E, Durak N, Kişlaoğlu E. "Tandir": an old and well known cause of burn injury in the Middle East. Burns 1998;24:654-7. [CrossRef]

7. Smith DL, Cairns BA, Ramadan F, Dalston JS, Fakhry SM, Rutledge R, et al. Effect of inhalation injury, burn size, and age on mortality: a study of 1447 consecutive burn patients. J Trauma 1994;37:655-9. [CrossRef]

8. McGwin G Jr, George RL, Cross JM, Rue LW. Improving the ability to predict mortality among burn patients. Burns 2008;34:320-7. [CrossRef]

9. Brusselaers N, Monstrey S, Snoeij T, Vandijck D, Lizy C, Hoste E, et al. Morbidity and mortality of bloodstream infections in patients with severe burn injury. Am J Crit Care 2010;19:e81-7. [CrossRef]

10. Al B, Güloğlu MN, Okur H, Öztürk H, Kara İH, Aldemir M. Doğu ve Güneydoğu Anadolu bölgelerinde haşlanma ve alev yanıklarının epidemiyolojik özellikleri. Tip Araştırma Derg 2005;3:14-21.

11. Seo DK, Kym D, Yim H, Yang HT, Cho YS, Kim JH, et al. Epidemiological trends and risk factors in major burns patients in South Korea: a 10-year experience. Burns 2015;41:181-18. [CrossRef]

12. You K, Yang HT, Kym D, Yoon J, Haejun Yim, Cho YS, et al. Inhalation injury in burn patients: establishing the link between diagnosis and prognosis. Burns 2014;40:1470-5. [CrossRef]

13. Jeschke MG, Pinto R, Kraft R, Nathens AB, Finnerty CC, Gamelli RL, et al; Inflammation and the Host Response to Injury Collaborative Research Program. Morbidity and survival probability in burn patients in modern burn care. Crit Care Med 2015;43:808-15. [CrossRef]

14. Herndon DN, Gore D, Cole M, Desai MH, Linares H, Abston S, et al. Determinants of mortality in pediatric patients with greater than $70 \%$ full-thickness total body surface area thermal injury treated by early total excision and grafting. J Trauma 1987;27:208-12. [CrossRef]

15. Housinger TA, Brinlerhoff C, Warden GD. The relationship between platelet counts, sepsis, and survival in pediatric burn patients. Arch Surg 1993;128:65-7. [CrossRef]

16. de Macedo JL, Rosa SC, Castro C. Sepsis in burned patients. Rev Soc Bras Med Trop 2003;36:647-52. [CrossRef]

17. Merrell SW, Saffle JR, Sullivan JJ, Larsen CM, Warden GD. Increased survival after major thermal injury. A nine year review. Am J Surg 1987;154:623-7. [CrossRef]

18. Gomez M, Wong DT, Stewart TE, Redelmeier DA, Fish JS. The FLAMES score accurately predicts mortality risk in burn patients. J Trauma 2008;65:636-45. [CrossRef]

19. Muller MJ, Pegg SP, Rule MR. Determinants of death following burn injury. Br J Surg 2001;88:583-7. [CrossRef]

20. O'Keefe GE, Hunt JL, Purdue GF. An evaluation of risk factors for mortality after burn trauma and the identification of gender-dependent differences in outcomes. J Am Coll Surg 2001;192:153-60. [CrossRef]

21. Zarei MR, Dianat S, Eslami V, Harirchi I, Boddouhi N, Zandieh A, et al. Factors associated with mortality in adult hospitalized burn patients in
Tehran. Ulus Travma Acil Cerrahi Derg 2011;17:61-5. [CrossRef]

22. Brusselaers N, Juhász I, Erdei I, Monstrey S, Blot S. Evaluation of mortality following severe burns injury in Hungary: external validation of a prediction model developed on Belgian burn data. Burns 2009;35:1009-14.

23. Ryan CM, Schoenfeld DA, Thorpe WP, Sheridan RL, Cassem EH, Tompkins RG. Objective estimates of the probability of death from burn injuries. N Engl J Med 1998;338:362-6. [CrossRef]

24. Wolf SE, Rose JK, Desai MH, Mileski JP, Barrow RE, Herndon DN. Mortality determinants in massive pediatric burns. An analysis of 103 children with $>$ or $=80 \%$ TBSA burns ( $>$ or $=70 \%$ full-thickness). Ann Surg 1997;225:554-569. [CrossRef]

25. Bessey PQ, Arons RR, Dimaggio CJ, Yurt RW. The vulnerabilities of age: burns in children and older adults. Surgery 2006;140:705-17. [CrossRef]

26. Al B, Yildirim C, Coban S, Aldemir M, Güloğlu C. Mortality factors in flame and scalds burns: Our experience in 816 patients. Ulus Travma Acil Cerrahi Derg 2009;15:599-606.

27. Haksal MC, Tiryaki C, Yazıcıoğlu MB, Güven M, Çiftci A, Esen O, et al. General characteristics of paint thinner burns: Single center experience. Ulus Travma Acil Cerrahi Derg 2017;23:51-5.

28. Lee KH, Hwang SJ, Kim SH, Lee SH, Yu DK, Hwang JH, et al. Comparison of mortality and morbidity in multiple versus singleton very low birth weight infants in a neonatal intensive care unit. J Korean Med Sci 2003;18:779-82. [CrossRef]

29. Ay N, Alp V, Aliosmanoğlu İ, Sevük U, Kaya Ş, Dinç B. Factors affecting morbidity and mortality in traumatic colorectal injuries and reliability and validity of trauma scoring systems. World J Emerg Surg 2015;10:21.

30. Tan Chor Lip H, Tan JH, Thomas M, Imran FH, Azmah Tuan Mat TN. Survival analysis and mortality predictors of hospitalized severe burn victims in a Malaysian burns intensive care unit. Burns Trauma 2019;7:3.

31. Panjeshahin MR, Lari AR, Talei A, Shamsnia J, Alaghehbandan R. Epidemiology and mortality of burns in the South West of Iran. Burns 2001;27:219-26. [CrossRef]

32. Kobayashi K, Ikeda H, Higuchi R, Nozaki M, Yamamoto Y, Urabe M, et al. Epidemiological and outcome characteristics of major burns in Tokyo. Burns 2005;31:S3-11. [CrossRef]

33. Laloë V. Epidemiology and mortality of burns in a general hospital of Eastern Sri Lanka. Burns 2002;28:778-81. [CrossRef]

34. Waller AE, Marshall SW, Langley JD. Adult thermal injuries in New Zealand resulting in death and hospitalization. Burns 1998;24:245-51.

35. Lionelli GT, Pickus EJ, Beckum OK, Decoursey RL, Korentager RA. A three decade analysis of factors affecting burn mortality in the elderly. Burns 2005;31:958-63. [CrossRef]

36. Albayrak Y, Albayrak A, Ylldız A, Aylu B. Clinical and demographic features of pediatric burns in the eastern provinces of Turkey. Scand J Trauma Resusc Emerg Med 2011;19:6. [CrossRef]

37. Carvajal HF. Fluid therapy for the acutely burned child. Compr Ther 1977;3:17-24.

38. Albertyn R, Bickler SW, Rode H. Paediatric burn injuries in Sub Saharan Africa--an overview. Burns. 2006;32:605-12. [CrossRef]

39. Ndiritu S, Ngumi ZW, Nyaim O. Burns: the epidemiological pattern, risk and safety awareness at Kenyatta National Hospital, Nairobi. East Afr Med J 2006;83:455-60. [CrossRef]

40. Okoro PE, Igwe PO, Ukachukwu AK. Childhood burns in south eastern Nigeria. Afr J Paediatr Surg 2009;6:24-7. [CrossRef]

41. Meshulam-Derazon S, Nachumovsky S, Ad-El D, Sulkes J, Hauben DJ. Prediction of morbidity and mortality on admission to a burn unit. Plast Reconstr Surg 2006;118:116-20. [CrossRef]

42. Tyson AF, Boschini LP, Kiser MM, Samuel JC, Mjuweni SN, Cairns BA, et al. Survival after burn in a sub-Saharan burn unit: challenges and opportunities. Burns 2013;39:1619-25. [CrossRef]

43. Fazeli S, Karami-Matin R, Kakaei N, Pourghorban S, Safari-Faramani R, Safari-Faramani B. Predictive factors of mortality in burn patients. Trau- 
ma Mon 2014;19:e14480. [CrossRef]

44. Mirza Aghazadeh A, Lotfi M, Ghahramanian A, Ahadi F. Lethal Area 50 in Patients with Burn Injuries in North West, Iran. J Caring Sci 2018;7:53-8. [CrossRef]

45. Koljonen V, Tuimala J, Haglund C, Tukiainen E, Vuola J, Juvonen E, et al. The Use of Blood Products in Adult Patients with Burns. Scand J Surg 2016;105:178-85. [CrossRef]

46. Palmieri TL, Caruso DM, Foster KN, Cairns BA, Peck MD, Gamelli RL, et al; American Burn Association Burn Multicenter Trials Group. Effect of blood transfusion on outcome after major burn injury: a multicenter study. Crit Care Med 2006;34:1602-7. [CrossRef]

47. Boral L, Kowal-Vern A, Yogore M 3rd, Patel H, Latenser BA. Transfusions in burn patients with/without comorbidities. J Burn Care Res 2009;30:268-73. [CrossRef]

48. Kwan P, Gomez M, Cartotto R. Safe and successful restriction of transfusion in burn patients. J Burn Care Res 2006;27:826-34. [CrossRef]

49. Lu RP, Lin FC, Ortiz-Pujols SM, Adams SD, Whinna HC, Cairns BA, et al. Blood utilization in patients with burn injury and association with clinical outcomes (CME). Transfusion 2013;53:2212-21; quiz 2211.

50. Graves TA, Cioffi WG, Mason AD Jr, McManus WF, Pruitt BA Jr. Relationship of transfusion and infection in a burn population. J Trauma 1989;29:948-54. [CrossRef]

51. Scornik JC, Meier-Kriesche HU. Blood transfusions in organ transplant patients: mechanisms of sensitization and implications for prevention. Am J Transplant 2011;11:1785-91. [CrossRef]

52. Refaai MA, Blumberg N. Transfusion immunomodulation from a clinical perspective: An update. Expert Rev Hematol 2013;6:653-63. [CrossRef]

53. Pham TN, Cancio LC, Gibran NS; American Burn Association. American Burn Association practice guidelines burn shock resuscitation.J Burn Care Res 2008;29:257-66. [CrossRef]

54. Sherren PB, Hussey J, Martin R, Kundishora T, Parker M, Emerson B. Acute burn induced coagulopathy. Burns 2013;39:1157-61. [CrossRef]
55. Palmieri TL, Greenhalgh DG, Sen S. Prospective comparison of packed red blood cell-to-fresh frozen plasma transfusion ratio of 4: 1 versus 1: 1 during acute massive burn excision. J Trauma Acute Care Surg 2013;74:76-83.

56. Melinyshyn A, Callum J, Jeschke MC, Cartotto R. Albumin supplementation for hypoalbuminemia following burns: unnecessary and costly!. J Burn Care Res 2013;34:8-17. [CrossRef]

57. Hunter JE, Drew PJ, Potokar TS, Dickson W, Hemington-Gorse SJ. Albumin resuscitation in burns: a hybrid regime to mitigate fluid creep. Scars Burn Heal 2016;2:2059513116642083. [CrossRef]

58. Albumin Reviewers (Alderson P, Bunn F, Li Wan Po A, Li L, Blackhall K, Roberts I, Schierhout G). Human albumin solution for resuscitation and volume expansion in critically ill patients. Cochrane Database Syst Rev 2011;(10):CD001208.

59. Wilkes MM, Navickis RJ. Patient survival after human albumin administration. A meta-analysis of randomized, controlled trials. Ann Intern Med 2001;135:149-64. [CrossRef]

60. Eljaiek R, Heylbroeck C, Dubois MJ. Albumin administration for fluid resuscitation in burn patients: A systematic review and meta-analysis. Burns 2017;43:17-24. [CrossRef]

61. Albayrak Y, Albayrak A, Albayrak F, Yildirim R, Aylu B, Uyanik A, et al. Mean platelet volume: a new predictor in confirming acute appendicitis diagnosis. Clin Appl Thromb Hemost 2011;17:362-6. [CrossRef]

62. Canpolat FE, Yurdakök M, Armangil D, Yiğit S. Mean platelet volume in neonatal respiratory distress syndrome. Pediatr Int 2009;51:314-6.

63. Zahorec R. Ratio of neutrophil to lymphocyte counts--rapid and simple parameter of systemic inflammation and stress in critically ill. Bratisl Lek Listy 2001;102:5-14.

64. Fuss J, Voloboyeva A, Poliovyj V. Prognostic value of using neutrophil-lymphocyte ratio in patients with burn injury for the diagnosis of sepsis and bacteraemia. Pol Przegl Chir 2018;90:13-6. [CrossRef]

65. Balta S, Demırkol S, Kucuk U. The platelet lymphocyte ratio may be useful inflammatory indicator in clinical practice. Hemodial Int 2013;17:668-9. [CrossRef]

\section{ORİJINAL ÇALIŞMA - ÖZET}

\section{Yanıklı hastalarda mortaliteyi etkileyen faktörler: Tek merkez sonuçları}

\section{Dr. Ayetullah Temiz, ${ }^{1}$ Dr. Ayşe Albayrak, ${ }^{2}$ Dr. Rıfat Peksöz, ${ }^{3}$ Dr. Esra Dışcı, ${ }^{4}$ Dr. Ercan Korkut, ${ }^{4}$ Dr. Yusuf Tanrıkulu, ${ }^{5}$ Dr. Yavuz Albayrak ${ }^{4}$}

${ }^{1}$ Erzurum Bölge Eğitim ve Araştırma Hastanesi, Genel Cerrahi Kliniği, Erzurum

${ }^{2}$ Atatürk Üniversitesi Tıp Fakültesi, Enfeksiyon Hastalıkları Anabilim Dalı, Erzurum

${ }^{3}$ Malazgirt Devlet Hastanesi, Genel Cerrahi Kliniği, Muş

${ }^{4}$ Atatürk Üniversitesi Tıp Fakültesi, Genel Cerrahi Anabilim Dalı, Erzurum

${ }^{5}$ KTO Karatay Üniversitesi Tıp Fakültesi, Genel Cerrahi Anabilim Dalı, Konya

AMAÇ: Yanıklar, hasta ve ailelerine ciddi fiziksel ve psikolojik morbidite meydana getirmeleri yanında önemli bir mortalite nedenidir. Ayrıca bu tür yaralanmalar, tedavi süreçleri ve bıraktığı sekeller nedeniyle önemli mali yükler de getirmektedir. Bu çalışmada amaç, yanık mortalitesini etkileyen faktörleri belirlemektir.

GEREÇ VE YÖNTEM: Yanık merkezimize Eylül 2008-Aralık 2016 yılları arasında yanık nedeni ile başvuran hastaların kayıtları incelendi. Hastaların mortaliteleri değerlendirilirken yaş, cinsiyet, yanık yüzey alanı yüzdesi, sevk durumu, yanma yeri, yanık derecesi, hastaneye başvuru için geçen süre, yanma etyolojisi, kan ve kan ürünleri alıp almaması, tam kan sayımı, rutin biyokimya, kuagülasyon parametreleri, C-reaktif protein (CRP), sedimentasyon hızı, nötrofil lenfosit oranı (NLR) ve trombosit-lenfosit oranı (PLR) gibi bazı laboratuvar değerleri incelendi.

BULGULAR: Toplam I 33 hasta çalışmaya dahil edildi. Hastanın yaşı $(p=0.00 \mathrm{I})$, yanık derecesi $(p<0.00 \mathrm{I})$, yanık yüzey alanı $(p<0.00 \mathrm{I})$, hastaneye başvuru süresi $(p<0.00 I)$, yanma etiyolojisi $(p<0.00 I)$, eritrosit süspansiyonu, Taze Donmuş Plazma ve albümin transfüzyonu verilmesi $(p<0.00 I)$, MPV $(p<0.00 I), N L R(p<0.00 I)$ ve PLR $(p<0.00 I)$ değerlerinin yanık hastalarında mortalite ile ilişkili olduğu tespit edildi.

TARTIŞMA: Bu çalışmada, hastanın yaşı, yanık derecesi, yanık yüzey alanı, hastaneye başvuru süresi, yanma etiyolojisi, eritrosit, TDP ve albümin transfüzyonu, MPV, NLR ve PLR değerlerinin yanık hastalarında mortalite ile ilişkili olduğu tespit edildi. Yaptığımız bu çalışma ile yanık hastaları değerlendirilirken mortalite ile ilişkili tespit edilen bu parametreler göz önünde bulundurularak hastaların mortalitesini azaltacak tedavi rehberlerinin oluşturulması sağlanabilir.

Anahtar sözcükler: Nötrofil lenfosit oranı; ortalama trombosit hacmi; trombosit-lenfosit oranı; yanık.

Ulus Travma Acil Cerrahi Derg 2020;26(5):777-783 doi: 10.14744/tjtes.2020.37862 